\title{
Association of MTHFR C677T variant genotype with serum folate and Vit B12 in Iranian patients with colorectal cancer or adenomatous polyps
}

Mahla Ghorbani ${ }^{1}$, Marjan Azghandi ${ }^{2,3}$, Reza Khayami ${ }^{4,5}$, Javad Baharara ${ }^{6}$ and Mohammad Amin Kerachian ${ }^{2,4,5^{*}}$

\begin{abstract}
Background: The incidence of colorectal cancer (CRC) has increased during recent years in Iran and other developing countries. Clinical studies suggest that essential folate dietary intake and moderate deficiency of methylenetetrahydrofolate reductase (MTHFR) may protect and reduce the risk of CRC. The present study aimed to investigate the clinical significance of C677T polymorphism within the MTHFR gene and its correlation with the serum folate and Vit $B_{12}$ in the Iranian population suffering from CRC.
\end{abstract}

Methods: Blood samples were taken from 1017 Iranian individuals (517 cases and 500 controls) who were referred for colonoscopy. TaqMan probe assay was performed for C677T MTHFR polymorphism. Sera were fractionated from the blood samples of 43 patients and controls and folate and Vit $B_{12}$ concentrations were measured by a monobind kit. The correlation of MTHFR polymorphisms and folate/vitamin- $B_{12}$ with CRC risk was analyzed.

Results: In the current study, we found the frequency of three different genotypes of MTHFR polymorphism in the Iranian population i.e., CC, CT, and TT, to be 51.31, 26.73, 21.96 and 61, 32.2, 6.8 in case and control groups, respectively. The homozygote genotype of MTHFR rs 1801133 polymorphism is associated with an increased risk of CRC by 3.68, 1.42, and 3.74-fold in codominant, dominant, and recessive models respectively ( $p$ value $<0.01$ ). Our study revealed that there was no significant difference between the amount of folate and Vit B12 in the case and control groups ( $p$ value $>0.05$ ).

Conclusions: This study revealed that there was no significant difference between the amount of folate and Vit $B_{12}$ in the case and control groups. Furthermore, our results demonstrated a higher risk association for 677TT and $677 T T+$ C677T genotypes of MTHFR compared with 677CC carriers among CRC patients.

Keywords: Colorectal cancer, C677T, MTHFR, Folate, Vitamin B12, TaqMan

*Correspondence: amin.kerachian@mail.mcgill.ca; kerachianma@mums.ac.ir

${ }^{5}$ Department of Medical Genetics, Faculty of Medicine, Mashhad University of Medical Sciences, Mashhad, Iran

Full list of author information is available at the end of the article

\section{Background}

Colorectal cancer (CRC) is the third most diagnosed cancer and the second leading cause of cancer death (about $1,900,000$ new cases and about 935,000 deaths) in the world [1]. This cancer is a multifactorial disease, involving genetic, epigenetic, and environmental risk factors $[2,3]$. Because of smoking and a Westernized diet (high 
intake of meat and fat), the incidence has also been raised in Iran during the recent decades [4-8].

It has been shown that the dietary Vit $\mathrm{B}_{12}$ alone or combined with other factors (e.g. folate), could affect different parts of the colon and rectal [9]. While folate is a vitamin B group involved in multiple biochemical processes, it acts as an important modulator of carcinogenesis.

Folic acid, the synthetic form of folate, is a pivotal nutrient in a one-carbon cycle, which has major roles in the synthesis of nucleotides and methylation reactions. Besides, the methylenetetrahydrofolate reductase (MTHFR) enzyme has crucial functions during synthesis, repair, and methylation of DNA, as well as a duty in circulating folate levels [10]. Several studies have reported the impact of folate intake on tumorigenesis by transforming the template of gene expression, which indicates an association of polymorphisms among folate metabolizing genes such as MTHFR and the establishment of CRC [11].

The MTHFR gene polymorphism is betided with single nucleotide variants within codon 677 in exon 4 (C to $\mathrm{T}$ or Ala to Val). The result of this variant is to encode a thermolabile enzyme with reduced activity causing a decreased plasma folate level [12-15]. The 677CC is the wild-type form of the MTHFR gene. The 677TT homozygous variant and the heterozygous CT genotype have less than $30 \%$ and $65 \%$ of the normal enzyme activity (wild type homozygous CC genotype), respectively [16].

In the current article, we studied the association between the risk of CRC and MTHFR C677T polymorphism and also investigated the correlation of the polymorphism with serum folate/Vit B12 concentrations in our patients.

\section{Methods}

\section{Study population and samples}

A total of 517 blood samples of colon disease patients (98 adenomas and 419 adenocarcinomas), as well as 500 normal blood samples, were collected from Reza Radiotherapy and Oncology Center (RRCO), Mashhad, Iran with the ethic committee approval of Mashhad University of Medical Sciences, Mashhad, Iran (grant\# 961906). Informed written consent had been obtained from all participants in this study. The control group was selected from individuals who were referred for a check-up colonoscopy without any diseases in the colon and rectum. In clinical evaluations, they had no serious GI diseases. Inclusion criteria for the patient group included patients who had positive colonoscopy reports for CRC and no first-relative family history of cancer. For the control group, inclusion criteria included individuals who had negative colonoscopy reports of CRC or any other colorectal diseases with no first-relative family history of cancer. Exclusion criteria for the patient and control groups were to identify a secondary GI disease during the study.

\section{MTHFR C677T polymorphism analysis}

MTHFR C677T polymorphism was detected in DNA extracted from whole blood by the use of real-time PCR (TaqMan ${ }^{\circledR}$ assay). The DNA was extracted from $300 \mathrm{ul}$ of blood using the standard salting-out method [17]. Primers and probes were synthesized by Bioneer Company (Bioneer Corporation, South Korea). The sequences of the primer and probe were as follows: primer forward, 5'-TGACCTGAAGCACTTGAAGGAGAA-3', primer reverse, 5'-GGAAGAATGTGTCAGCCTCAA AGA- $3^{\prime}$, probe C, 5'-ATGAAATCGGCTCCCG-3' (reporter: FAM), probe $\mathrm{T}, 5^{\prime}$-ATGAAATCGACTCCCG$3^{\prime}$ (reporter $\mathrm{Cy} 5$ ).

\section{Folate and vitamin B12 measurement}

Serum folate and vitamin $B_{12}$ measurements were a total of 43 samples in the case and control groups. For this reason, $5 \mathrm{~mL}$ of blood was collected, and the serum was obtained by a centrifugation method. Serum was then stored frozen at $-80^{\circ} \mathrm{C}$ until the time of usage. The determination of serum folate/vitamin B12 was done using ACCUBIND ELISA folate/Vit B12 test system kits (Monobind Inc., Lake Forest, CA 92630, USA).

\section{Statistical analysis}

With the power of $85 \%$ and a significance level, prevalence, disease allele frequency, and genotype relative risk (RR) of $0.05,0.0075,0.23$, and 1.38 , respectively a sample size of 419 in the case group and 500 in the control group were calculated.

Association analyses were performed using SNPassoc [18]. The Hardy-Weinberg equilibrium (HWE) and the p-value for categorical variables were calculated by chisquare test. Mann-Whitney $U$ test was used to establish the difference in levels of folate and Vit B12.

\section{Results}

The association between the risk of CRC and MTHFR C677T polymorphism and the correlation of the polymorphism with serum folate/Vit B12 concentrations in Iranian patients were investigated. The details of age, gender distribution, and demographic characteristics of samples were shown in Tables 1 and 2. Moreover, the percentage of genotypes in different groups; normal, adenoma and adenocarcinoma has been indicated in Tables 1 and 3. Table 3 shows that the control group follows the Hardy Weinberg equilibrium. Notably, CRC patients and controls demonstrated significantly different frequencies for the rs 1801133 alleles. Allele T carriers 
Table 1 Descriptive table of demographic variables

\begin{tabular}{lllc}
\hline & Control* $^{*}$ & Case $^{* *}$ & p-value \\
\hline Age $^{\text {a }}$ & & & \\
$<45$ & $229(45.8 \%)$ & $86(20.5 \%)$ & $<0.001$ \\
$\geq 45$ & $271(54.2 \%)$ & $333(79.5 \%)$ & \\
Sex & & & \\
Female & $261(52.2 \%)$ & $200(47.7 \%)$ & 0.2 \\
Male & $239(47.8 \%)$ & $219(52.3 \%)$ & \\
Addiction & & & \\
No & $387(77.4 \%)$ & $353(84.2 \%)$ & 0.0115 \\
Yes & $113(22.6 \%)$ & $66(15.8 \%)$ & \\
Tumor location & & & \\
Colon & & $206(49.2 \%)$ & \\
Rectosigmoid & & $213(50.8 \%)$ & \\
\hline
\end{tabular}

* Number of controls: 500; ** number of cases: 419 ; Chi-squared test was used to determine the $p$-value; a cut off of 45 years old was determined for age according to American Cancer Society Guidelines and US Preventive Services Task Force Recommendation Statement $[19,20]$; ${ }^{b}$ type of addiction $=$ smoking (cigarette, hookah, opium)

Table 2 MTHFR 677 T polymorphism in adenoma samples

\begin{tabular}{lr}
\hline & N \\
\hline Sex & \\
Female & 48 \\
Male & 50 \\
Genotype & \\
Tubular adenoma/CC & 41 \\
Tubular adenoma/CT & 30 \\
Tubular adenoma/TT & 3 \\
Tubulovillous adenoma/CC & 4 \\
Tubulovillous adenoma/CT & 11 \\
Tubulovillous adenoma/TT & 5 \\
Serrated adenoma/CC & 1 \\
Traditional serrated adenoma/CT & 2 \\
Villous/CC & 1 \\
Location & \\
Anal & 1 \\
Rectum & 28 \\
Sigmoid & 46 \\
Transverse colon & 0 \\
Descending colon & 8 \\
Ascending colon & 12 \\
Cecum & 3 \\
Dysplasia & \\
Low grade & 80 \\
High grade & 18 \\
\hline Meanage & \\
\hline
\end{tabular}

Mean age $=57, \max =80, \min =27$
Table 3 Allelic distribution and Hardy Weinberg equilibrium

\begin{tabular}{llll}
\hline Genotypes & Frequency (\%) & & \\
\cline { 2 - 4 } & Whole population & Controls & Cases \\
\hline $\mathrm{C} / \mathrm{C}$ & $520(56.58 \%)$ & $305(61 \%)$ & $215(51.31 \%)$ \\
$\mathrm{C} / \mathrm{T}$ & $273(29.71 \%)$ & $161(32.2 \%)$ & $112(26.73 \%)$ \\
$\mathrm{T} / \mathrm{T}$ & $126(13.71 \%)$ & $34(6.8 \%)$ & $92(21.96 \%)$ \\
Alleles & & & \\
$\mathrm{C}$ & $1313(71.44 \%)$ & $771(77.1 \%)$ & $542(64.68 \%)$ \\
$\mathrm{T}$ & $525(28.56 \%)$ & $229(22.9 \%)$ & $296(35.32 \%)$ \\
HWE (p value) & $8.07 \mathrm{E}-16$ & 0.0566881 & $2.93 \mathrm{E}-17$ \\
\hline
\end{tabular}

have an $84 \%$ higher risk of CRC than allele $C$ carriers $(\mathrm{OR}=1.84,95 \%$ CI $1.5-2.26, \mathrm{p}=5.31 \mathrm{e}-09)$.

Table 4 represents the association analysis for each genetic model. Our data showed that homozygote TT carriers, compared with CC genotype, were associated with an increased risk of CRC both before and after adjustment for sex, age, and addiction $(\mathrm{OR}=3.68$; $95 \%$ CI $2.35-5.75, \mathrm{p}=2.516 \mathrm{e}-09)$. Besides, the recessive model showed that individuals with TT genotype had a higher risk of CRC than $\mathrm{C}$ allele carriers $(\mathrm{CC}+\mathrm{CT})$ $(\mathrm{OR}=3.74$ 95\% CI 2.42-5.78, $\mathrm{p}=3.291 \mathrm{e}-10)$. Furthermore, the dominant model indicated that $\mathrm{T}$ allele carriers had a $42 \%$ higher risk of CRC after adjustment compared with $\mathrm{CC}$ homozygotes $(\mathrm{OR}=1.42$ 95\% CI 1.08-1.87, $\mathrm{p}=1.134 \mathrm{e}-02)$.

In subgroup analysis, TT genotype of rs1801133 polymorphism was associated with an increased risk in both colon and rectosigmoid cancer sites compared with CC homozygotes and $\mathrm{C}$ allele carriers (Table 5 ).

Tables 6 and 7 show the association of characteristic variables with genotypes. In Table 5 , regardless of the genotype, patients 45 and over 45 years of age had a more pronounced risk effect than patients under 45 . In this regard, patients with TT genotype represented the highest risk association $(\geq 45 \mathrm{TT}$ vs. $<45 \mathrm{TT}$ : OR $=5.4$ 95\% CI 2.21-13.19). In addition, participants with homozygote TT genotype and addiction were associated with a lower risk of cancer in comparison with TT carriers who did not have an addiction (addicted TT vs. not addicted TT, OR $=0.33$ 95\% CI 0.13-0.81). Stratified analysis (Table 7) showed that within each gender group, the TT genotype was associated with a higher risk of CRC in comparison with CC carriers (female TT vs. female CC: $\mathrm{OR}=4.8995 \%$ CI 2.67-8.97; male TT vs. male CC: $O R=3.0195 \%$ CI $1.63-5.57)$. Similarly, within each age group, homozygotes for the alternate allele showed an increased risk for both groups in comparison with CC genotype $(<45$ TT vs. $<45$ CC: $\mathrm{OR}=2.3195 \%$ CI $1.04-5.13 ; \geq 45$ TT vs. $\geq 45$ CC: 
Table 4 The association analysis for each genetic model

\begin{tabular}{|c|c|c|c|c|c|c|c|}
\hline Model & Genotype & Control (\%) & Case (\%) & OR (Cl95\%) & P-value & $\mathrm{OR}^{\mathrm{a}}(\mathrm{Cl} 95 \%)$ & $P$-value ${ }^{a}$ \\
\hline \multirow[t]{3}{*}{ Codominant } & $C / C$ & 305 (61\%) & $215(51.3 \%)$ & Ref & & Ref & \\
\hline & $C / T$ & 161 (32.2\%) & 112 (26.7\%) & $0.99(0.73-1.33)$ & 0.931 & $0.95(0.70-1.29)$ & 0.74361 \\
\hline & $T / T$ & $34(6.8 \%)$ & $92(22 \%)$ & $3.84(2.50-5.90)$ & $9.01 e-10$ & $3.68(2.35-5.75)$ & $1.20 \mathrm{e}-08$ \\
\hline \multirow[t]{2}{*}{ Dominant } & $C / C$ & 305 (61\%) & 215 (51.3\%) & Ref & & Ref & \\
\hline & $\mathrm{C} / \mathrm{T}-\mathrm{T} / \mathrm{T}$ & 195 (39\%) & 204 (48.7\%) & $1.48(1.14-1.93)$ & 0.00322 & $1.42(1.08-1.87)$ & 0.0114 \\
\hline \multirow[t]{2}{*}{ Recessive } & $\mathrm{C} / \mathrm{C}-\mathrm{C} / \mathrm{T}$ & 466 (93.2\%) & $327(78 \%)$ & Ref & & Ref & \\
\hline & $\mathrm{T} / \mathrm{T}$ & $34(6.8 \%)$ & 92 (22\%) & $3.86(2.54-5.86)$ & $2.48 \mathrm{e}-10$ & $3.74(2.42-5.78)$ & $2.72 e-09$ \\
\hline \multirow[t]{2}{*}{ Over dominant } & $\mathrm{C} / \mathrm{C}-\mathrm{T} / \mathrm{T}$ & $339(67.8 \%)$ & 307 (73.3\%) & Ref & & Ref & \\
\hline & $\mathrm{C} / \mathrm{T}$ & 161 (32.2\%) & $112(26.7 \%)$ & $0.77(0.58-1.02)$ & 0.071 & $0.74(0.55-1.00)$ & 0.0528 \\
\hline log-Additive & $0,1,2$ & $500(54.4 \%)$ & $419(45.6 \%)$ & $1.62(1.35-1.95)$ & $1.842 \mathrm{e}-07$ & $1.58(1.30-1.91)$ & $2.353 e-06$ \\
\hline
\end{tabular}

Bold indicates a p-value less than 0.05 is statistically significant

${ }^{\text {a }}$ Adjusted for age, sex, and addiction

Table 5 The association analysis stratified for tumor location

\begin{tabular}{|c|c|c|c|c|c|c|c|c|}
\hline Location & Model & Genotype & Control (\%) & Case (\%) & OR $(95 \% \mathrm{Cl})$ & P-value & $\mathrm{OR}^{\mathrm{a}}$ & $P$-value ${ }^{a}$ \\
\hline \multirow[t]{10}{*}{ Colon } & \multirow[t]{3}{*}{ Codominant } & $\mathrm{C} / \mathrm{C}$ & 305 (61\%) & 105 (51\%) & Ref & \multirow[t]{3}{*}{$2.17 e-05$} & Ref & \multirow[t]{3}{*}{$5.30 \mathrm{e}-05$} \\
\hline & & $\mathrm{C} / \mathrm{T}$ & $161(32.2 \%)$ & $62(30.1 \%)$ & $1.12(0.77-1.62)$ & & $1.1(0.76-1.6)$ & \\
\hline & & $\mathrm{T} / \mathrm{T}$ & $34(6.8 \%)$ & 39 (18.9\%) & $3.33(2-5.55)$ & & $3.27(1.93-5.54)$ & \\
\hline & \multirow[t]{2}{*}{ Dominant } & $\mathrm{C} / \mathrm{C}$ & $305(61 \%)$ & 105 (51\%) & Ref & \multirow[t]{2}{*}{0.014404} & Ref & \multirow[t]{2}{*}{0.021843} \\
\hline & & $\mathrm{C} / \mathrm{T}-\mathrm{T} / \mathrm{T}$ & 195 (39\%) & $101(49 \%)$ & $1.5(1.08-2.09)$ & & $1.48(1.06-2.07)$ & \\
\hline & \multirow[t]{2}{*}{ Recessive } & $\mathrm{C} / \mathrm{C}-\mathrm{C} / \mathrm{T}$ & 466 (93.2\%) & 167 (81.1\%) & Ref & \multirow[t]{2}{*}{$4.31 e-06$} & Ref & \multirow[t]{2}{*}{$1.04 e-05$} \\
\hline & & $\mathrm{T} / \mathrm{T}$ & $34(6.8 \%)$ & 39 (18.9\%) & $3.2(1.96-5.24)$ & & $3.16(1.9-5.26)$ & \\
\hline & \multirow[t]{2}{*}{ Over dominant } & $\mathrm{C} / \mathrm{C}-\mathrm{T} / \mathrm{T}$ & 339 (67.8\%) & 144 (69.9\%) & Ref & \multirow[t]{2}{*}{0.583813} & Ref & \multirow[t]{2}{*}{0.558616} \\
\hline & & $\mathrm{C} / \mathrm{T}$ & 161 (32.2\%) & $62(30.1 \%)$ & $0.91(0.64-1.29)$ & & $0.9(0.63-1.29)$ & \\
\hline & log-Additive & $0,1,2$ & 500 (70.8\%) & 206 (29.2\%) & $1.6(1.26-2.02)$ & $9.44 e-05$ & $1.57(1.24-2)$ & 0.000217 \\
\hline \multirow[t]{10}{*}{ Rectosigmoid } & \multirow[t]{3}{*}{ Codominant } & $\mathrm{C} / \mathrm{C}$ & 305 (61\%) & $110(51.6 \%)$ & Ref & \multirow[t]{3}{*}{$7.24 \mathrm{e}-10$} & Ref & \multirow[t]{3}{*}{$5.88 \mathrm{e}-09$} \\
\hline & & $C / T$ & $161(32.2 \%)$ & $50(23.5 \%)$ & $0.86(0.59-1.27)$ & & $0.79(0.53-1.18)$ & \\
\hline & & $\mathrm{T} / \mathrm{T}$ & $34(6.8 \%)$ & $53(24.9 \%)$ & $4.32(2.67-7)$ & & $4.16(2.48-6.96)$ & \\
\hline & \multirow[t]{2}{*}{ Dominant } & $\mathrm{C} / \mathrm{C}$ & $305(61 \%)$ & $110(51.6 \%)$ & Ref & \multirow[t]{2}{*}{0.020807} & Ref & \multirow[t]{2}{*}{0.080438} \\
\hline & & $\mathrm{C} / \mathrm{T}-\mathrm{T} / \mathrm{T}$ & $195(39 \%)$ & 103 (48.4\%) & $1.46(1.06-2.02)$ & & $1.35(0.96-1.9)$ & \\
\hline & \multirow[t]{2}{*}{ Recessive } & $\mathrm{C} / \mathrm{C}-\mathrm{C} / \mathrm{T}$ & 466 (93.2\%) & $160(75.1 \%)$ & Ref & \multirow[t]{2}{*}{$1.17 e-10$} & Ref & \multirow[t]{2}{*}{$1.49 \mathrm{e}-09$} \\
\hline & & $\mathrm{T} / \mathrm{T}$ & $34(6.8 \%)$ & 53 (24.9\%) & $4.54(2.85-7.24)$ & & $4.5(2.73-7.41)$ & \\
\hline & \multirow[t]{2}{*}{ Over dominant } & $\mathrm{C} / \mathrm{C}-\mathrm{T} / \mathrm{T}$ & 339 (67.8\%) & $163(76.5 \%)$ & Ref & \multirow[t]{2}{*}{0.017874} & Ref & \multirow[t]{2}{*}{0.006936} \\
\hline & & $\mathrm{C} / \mathrm{T}$ & $161(32.2 \%)$ & $50(23.5 \%)$ & $0.65(0.45-0.93)$ & & $0.59(0.4-0.87)$ & \\
\hline & log-Additive & $0,1,2$ & $500(70.1 \%)$ & $213(29.9 \%)$ & $1.71(1.37-2.14)$ & $2.54 \mathrm{e}-06$ & $1.64(1.29-2.07)$ & $3.75 e-05$ \\
\hline
\end{tabular}

Bold indicates a p-value less than 0.05 is statistically significant

${ }^{\text {a }}$ Adjusted for age, sex, and addiction

$\mathrm{OR}=4.3495 \%$ CI $2.49-7.56$ ). Finally, in the no addiction group, TT genotype was also associated with increased risk of CRC in comparison with CC genotype of the same group (no addiction TT vs. no addiction CC: $\mathrm{OR}=4.6195 \%$ CI 2.76-7.69).

The median concentration of serum Vit B12 was 298 and $293 \mathrm{pg} / \mathrm{ml}$ in cancer and normal groups, respectively. The median concentration of folic acid in cancer and normal groups was calculated at 11.4 and 9.2, respectively (Table 8). As illustrated in Fig. 1 and
Table 8, there was no significant difference between the amount of folic acid and Vit $\mathrm{B}_{12}$ in cancer and normal groups $(\mathrm{P}=0.202$ and 0.951 , respectively).

\section{Discussion}

In the present study, among CRC patients an increase in 677TT MTHFR polymorphisms has been indicated.

Previous studies on the association of C677T polymorphism and susceptibility to CRC revealed no constant results. Some studies suggested a protective effect 
Table 6 The associations of the clinical characteristics within genotype

\begin{tabular}{|c|c|c|c|c|c|c|}
\hline Genotype & Clinical feature & Characteristic & Control & Case & OR $(95 \% \mathrm{Cl})$ & P-value \\
\hline \multirow[t]{2}{*}{$\mathrm{C} / \mathrm{C}$} & Sex & Female & 155 & 95 & Ref & \\
\hline & & Male & 150 & 120 & $1.31(0.92-1.85)$ & 0.136287 \\
\hline \multirow[t]{2}{*}{$C / T$} & & Female & 89 & 54 & Ref & \\
\hline & & Male & 72 & 58 & $1.33(0.82-2.15)$ & 0.25070 \\
\hline \multirow[t]{2}{*}{$\mathrm{T} / \mathrm{T}$} & & Female & 17 & 51 & Ref & \\
\hline & & Male & 17 & 41 & $0.8(0.37-1.77)$ & 0.587 \\
\hline \multirow[t]{2}{*}{ C/C } & Age & $<45$ & 142 & 50 & Ref & \\
\hline & & $\geq 45$ & 163 & 165 & $2.87(1.95-4.24)$ & $9.77 e-08$ \\
\hline \multirow[t]{2}{*}{$\mathrm{C} / \mathrm{T}$} & & $<45$ & 71 & 23 & Ref & \\
\hline & & $\geq 45$ & 90 & 89 & $3.05(1.75-5.31)$ & $7.88 e-05$ \\
\hline \multirow[t]{2}{*}{$\mathrm{T} / \mathrm{T}$} & & $<45$ & 16 & 13 & Ref & \\
\hline & & $\geq 45$ & 18 & 79 & $5.4(2.21-13.19)$ & 0.000214 \\
\hline \multirow[t]{2}{*}{$\mathrm{C} / \mathrm{C}$} & Addiction & No & 234 & 180 & Ref & \\
\hline & & Yes & 71 & 35 & $0.64(0.41-1)$ & 0.05210 \\
\hline \multirow[t]{2}{*}{$\mathrm{C} / \mathrm{T}$} & & No & 131 & 95 & Ref & \\
\hline & & Yes & 30 & 17 & $0.78(0.41-1.5)$ & 0.4577 \\
\hline \multirow[t]{2}{*}{$\mathrm{T} / \mathrm{T}$} & & No & 22 & 78 & Ref & \\
\hline & & Yes & 12 & 14 & $0.33(0.13-0.81)$ & 0.016 \\
\hline
\end{tabular}

Bold indicates a p-value less than 0.05 is statistically significant

Table 7 The associations of the genotype within clinical characteristics

\begin{tabular}{|c|c|c|c|c|c|c|}
\hline Clinical feature & Characteristic & Genotype & Control & Case & OR $(95 \% \mathrm{CI})$ & P-value \\
\hline \multirow[t]{6}{*}{ Sex } & Female & $\mathrm{C} / \mathrm{C}$ & 155 & 95 & Ref & \\
\hline & & $C / T$ & 89 & 54 & $0.99(0.65-1.5)$ & 0.962720 \\
\hline & & $\mathrm{T} / \mathrm{T}$ & 17 & 51 & $4.89(2.67-8.97)$ & $2.72 \mathrm{e}-07$ \\
\hline & Male & $\mathrm{C} / \mathrm{C}$ & 150 & 120 & Ref & \\
\hline & & $C / T$ & 72 & 58 & $1.01(0.66-1.53)$ & 0.97430 \\
\hline & & $T / T$ & 17 & 41 & $3.01(1.63-5.57)$ & 0.00043 \\
\hline \multirow[t]{6}{*}{ Age } & $<45$ & $\mathrm{C} / \mathrm{C}$ & 142 & 50 & Ref & \\
\hline & & $C / T$ & 71 & 23 & $0.92(0.52-1.63)$ & 0.7744 \\
\hline & & $\mathrm{T} / \mathrm{T}$ & 16 & 13 & $2.31(1.04-5.13)$ & 0.0404 \\
\hline & $\geq 45$ & $C / C$ & 163 & 165 & Ref & \\
\hline & & $C / T$ & 90 & 89 & $0.98(0.68-1.41)$ & 0.900 \\
\hline & & $\mathrm{T} / \mathrm{T}$ & 18 & 79 & $4.34(2.49-7.56)$ & $2.30 \mathrm{e}-07$ \\
\hline \multirow[t]{6}{*}{ Addiction $^{a}$} & No & $\mathrm{C} / \mathrm{C}$ & 234 & 180 & Ref & \\
\hline & & $C / T$ & 131 & 95 & $0.94(0.68-1.31)$ & 0.72454 \\
\hline & & $\mathrm{T} / \mathrm{T}$ & 22 & 78 & $4.61(2.76-7.69)$ & $4.76 e-09$ \\
\hline & Yes & $\mathrm{C} / \mathrm{C}$ & 71 & 35 & Ref & \\
\hline & & $C / T$ & 30 & 17 & $1.15(0.56-2.36)$ & 0.704302 \\
\hline & & $\mathrm{T} / \mathrm{T}$ & 12 & 14 & $2.37(0.99-5.65)$ & 0.052515 \\
\hline
\end{tabular}

Bold indicates a p-value less than 0.05 is statistically significant

${ }^{\text {a }}$ Type of addiction = smoking (cigarette, hookah, opium)

of TT genotype for colon cancer because a reduced risk of CRC progress was observed in TT individuals with a sufficient folate intake [19]. Chen et al. performed the first study to investigate the relation between the MTHFR C677T polymorphism and CRC. According to their results, the MTHFR C677T polymorphism affected enzyme activity and was involved in aberrant methylation and DNA synthesis, resulting in colorectal tumorigenesis [20]. Similar findings were subsequently reported by Slattery et al. [21], Ma et al. [22], and Le 
Table 8 Statistical analysis of folate and Vit B12 in adenocarcinoma and normal samples

\begin{tabular}{|c|c|c|c|c|c|}
\hline \multicolumn{3}{|l|}{ Vit B12 } & \multicolumn{3}{|l|}{ Folic acid } \\
\hline & Case $(\mathrm{N}=19)$ & Control $(\mathrm{N}=23)$ & & Case $(\mathrm{N}=17)$ & Control $(\mathrm{N}=22)$ \\
\hline High (> 982 pg/ml) & 4 & 2 & Normal (>5.38 ng/ml) & 17 & 19 \\
\hline Low $(<193$ pg/ml) & 2 & 4 & Deficient $(\leq 5.38 \mathrm{ng} / \mathrm{ml})$ & 0 & 3 \\
\hline Normal (193-982 pg/ml) & 13 & 17 & & & \\
\hline$x^{2}$ & 1.4993 & & $x^{2}$ & 0.95805 & \\
\hline P & 0.4725 & & $P$ & 0.3277 & \\
\hline Median $\left(\operatorname{mad}^{*}\right)$ & $298(130.47)$ & $293(127.5)$ & & $11.4(8.01)$ & $9.2(5.56)$ \\
\hline
\end{tabular}

*Median absolute deviation
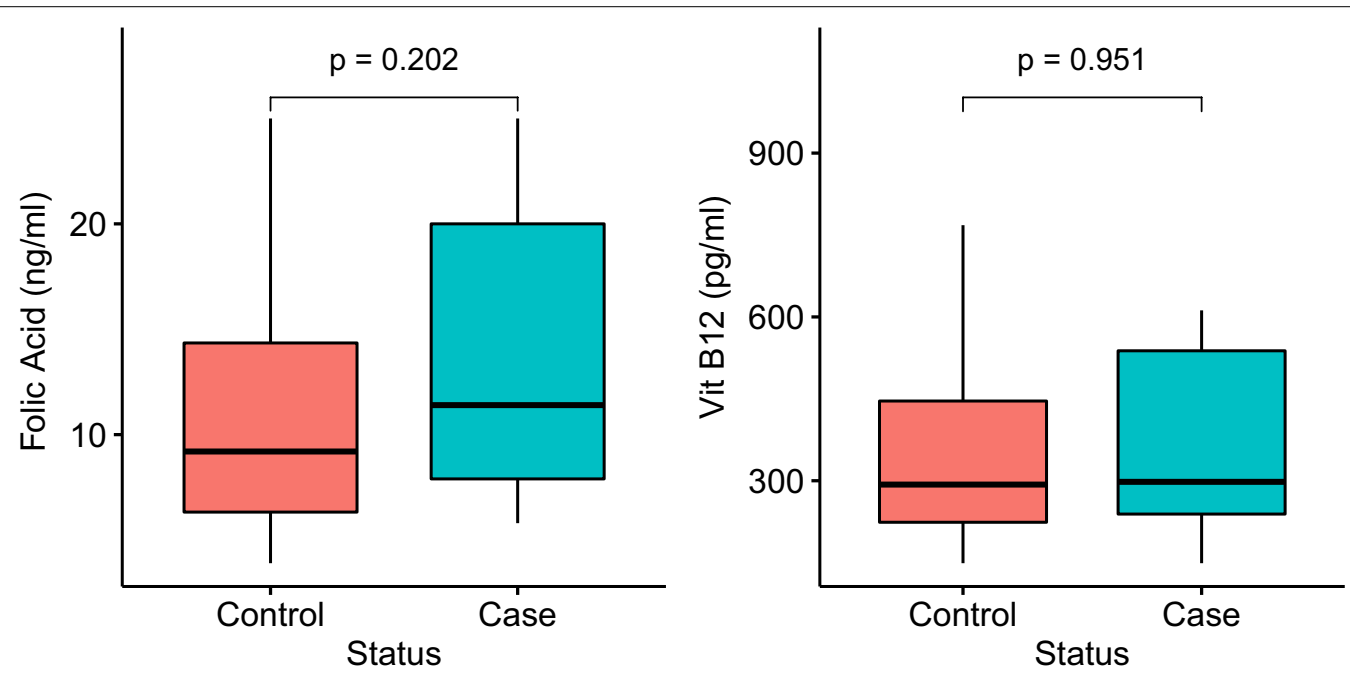

Fig. 1 Comparison of folic acid and vitamin B12 levels between cases and controls. p-value was calculated using Mann-Whitney U test and $p$-value $<0.05$ was defined as significant

Marchand et al. [23]. However, due to statistically nonsignificant findings, several other published studies failed to support an impact of MTHFR gene polymorphisms on CRC risk [24-26].

It has been shown that the effect of 677TT MTHFR polymorphism, the phenotype of valine amino acid, significantly depends on folate intake. An in-vitro study on HCT116 colon carcinoma cells reported the association of valine amino acid (TT genotype) with increased genomic DNA methylation in an adequate folate level and a significantly lower DNA genomic methylation in folate deficiency suggested folate as a genotype modifier. Biochemical changes in the valine-containing enzyme are important, which shows the enzyme stabilization by the addition of 5-methyltetrahydrofolate (5-MTHF) to the culture medium. Therefore, folate might modify the correlation between SNPs and the CRC risk [27]. According to Kennedy et al., MTHFR 677TT genotype was linked to a lower incidence of CRC. Furthermore, the associated risk of CRC was decreased for both the MTHFR 677 CC and TT genotypes when total folate intake was high [28].

The migration and proliferation of cancer cells are two important events in cancer development. The main cause of death for cancer patients is metastasis, migration of cancerous cells from one organ to other organs. It has been demonstrated that about $10 \mu \mathrm{M}$ folic acid reduced the migration and proliferation of human cell lines (COLO-205, LoVo, and HT-29) [29].

It has also been reported that the MTHFR 677TT genotype is one strong reason to lower the risk of proximal colon cancer. The site-specific analysis indicated the role of different molecular alterations in carcinogenesis in the proximal and distal of the colon and rectum. The more frequent genetic alterations in the distal side of the colon are K-ras and P53 mutations but microsatellite instability (MSI) is more frequent in the proximal site in CRC [15, 30, 31]. Decreased risk of distal colon cancer, rectal cancer, and proximal colon cancer has been reported to 
be associated with the 677TT genotype [16]. However, in the present study, we found an increase of CRC risk in MTHFR TT and TT + CT genotypes compared to CC genotype $(\mathrm{OR}=3.68$ 95\% CI 2.35-5.75; $\mathrm{OR}=1.4295 \%$ CI 1.08-1.87, respectively). We also found that regardless of tumor site individuals with MTHFR 677TT genotype were associated with higher risk than $\mathrm{C}$ allele carriers (Colon: OR $=3.16$ 95\% CI 1.9-5.26; Rectosigmoid: OR $=4.595 \%$ CI 2.73-7.41). Similarly, two studies on the Iranian population on 406 (175 cases, 231 controls) and 491 (234 cases, 257 controls) subjects, respectively reported that $\mathrm{CC}$ genotype has a protective effect on CRC [5, 32]. Although a more recent combined case-control study and meta-analysis on 2421 subjects have shown no significant association between MTHFR C677T polymorphism and the risk of CRC in the Iranian population suggesting the need for bigger sample size for MTHFR association studies [33]. There are also some reports indicating the increased risk of TT genotype in other populations [34, 35].

Some studies have reported a reduced risk of developing CRC with only TT genotype with a sufficient folate intake, suggesting a protective effect against CRC [21, 22]. In high folate intake cases, the risk of CRC risk is reduced for both MTHFR 677CC and 677TT genotypes [36]. Similarly, others have also reported the association of high-methyl diets like high folate dietary intake and low alcohol consumption with the protective effect of MTHFR 677TT genotype [16, 20, 23, 37, 38], although not everyone was able to demonstrate the protective effect of the MTHFR 677TT genotype even in high folate dietary intake [39-41]. However, it seems to be an association between the MTHFR polymorphism and dietary methyl supply, although the relationship remains inconsistent.

Even though we genotyped the MTHFR polymorphism in 1017 blood samples, there was still a limited sample size for folate and Vit B12 measurement that hindered us from incorporating this part of data into a comprehensive association study. Concerning the pilot study based on the limited number of samples for folate and Vit B12 measurement, further investigations are needed to support our findings. Furthermore, due to the heterogeneity of the Iranian population, there is an inevitable need for more multicentric studies in the Iranian population.

\section{Conclusions}

In summary, our study revealed that there was no significant difference between the amount of folate and Vit $B_{12}$ in the case and control groups. Furthermore, our results demonstrated a higher risk association for 677TT and $677 \mathrm{TT}+\mathrm{C677T}$ genotypes of MTHFR compared with 677CC carriers among CRC patients in Iran.

\section{Abbreviations}

MTHFR: Methylenetetrahydrofolate reductase; CRC: Colorectal cancer; SNP: Single nucleotide polymorphism.

\section{Acknowledgements}

We thank Mashhad University of Medical Sciences and Reza Radiotherapy and Oncology Center for supporting this study.

\section{Authors' contributions}

MAK and JB were responsible for writing the paper and the original draft. MAK was responsible for the study's conception. MG and MA were responsible for the investigation and conducting the experiments. RK prepared a figure and statistical analysis of data. All authors were responsible for reviewing and editing the final version of the paper. All authors read and approved the final manuscript.

\section{Funding}

This study was supported financially by Mashhad University of Medical Sciences (Grant number: 961906).

\section{Availability of data and materials}

The datasets created during the current study are not publicly accessible due to the possibility of compromising the privacy of individuals. According to the written approval forms accepted by the Ethics Committee of the Mashhad University of Medical Sciences (MUMS), the data will only be available to researchers within project. The data could be available upon request from the corresponding author, Dr Mohammad Amin Kerachian (according to the MUMS rules and regulations).

\section{Declarations}

\section{Ethics approval and consent to participate}

This study was ethically approved by the ethics committee approval of Mashhad University of Medical Sciences, Mashhad, Iran (grant \#961906) and all methods were performed in accordance with the relevant guidelines and regulations of The Declaration of Helsinki (DoH). Informed written consent had been obtained from all participants in this study.

\section{Consent to publish}

Not applicable.

\section{Competing interests}

The authors declare no conflict of interest for this research.

\section{Author details}

${ }^{1}$ Department of Biology, Faculty of Sciences, Mashhad Branch, Islamic Azad University, Mashhad, Iran. ${ }^{2}$ Cancer Genetics Research Unit, Reza Radiotherapy and Oncology Center, Mashhad, Iran. ${ }^{3}$ Department of Animal Science, Faculty of Agriculture, Ferdowsi University of Mashhad, Mashhad, Iran. ${ }^{4}$ Medical Genetics Research Center, Mashhad University of Medical Sciences, Mashhad, Iran. ${ }^{5}$ Department of Medical Genetics, Faculty of Medicine, Mashhad University of Medical Sciences, Mashhad, Iran. ${ }^{6}$ Research Center for Animal Development Applied Biology and Biology Department, Mashhad Branch, Islamic Azad University, Mashhad, Iran.

Received: 28 March 2021 Accepted: 8 October 2021

Published online: 13 October 2021

\section{References}

1. Sung H, Ferlay J, Siegel RL, Laversanne M, Soerjomataram I, Jemal A, Bray F. Global cancer statistics 2020: GLOBOCAN estimates of incidence and mortality worldwide for 36 cancers in 185 countries. CA Cancer J Clin. 2021;6:66.

2. Kerachian MA, Kerachian M. Long interspersed nucleotide element-1 (LINE-1) methylation in colorectal cancer. Clin Chim Acta. 2019:488:209-14. 
3. Rokni P, Shariatpanahi AM, Sakhinia E, Kerachian MA. BMP3 promoter hypermethylation in plasma-derived cell-free DNA in colorectal cancer patients. Genes Genomics. 2018;40(4):423-8.

4. Gandomani HS, Aghajani M, Mohammadian-Hafshejani A, Tarazoj AA, Pouyesh V, Salehiniya H. Colorectal cancer in the world: incidence, mortality and risk factors. Biomed Res Ther. 2017;4(10):1656-75.

5. Naghibalhossaini F, Mokarram P, Khalili I, Vasei M, Hosseini SV, Ashktorab H, Rasti M, Abdollahi K. MTHFR C677T and A1298C variant genotypes and the risk of microsatellite instability among Iranian colorectal cancer patients. Cancer Genet Cytogenet. 2010;197(2):142-51.

6. Arnold M, Sierra MS, Laversanne M, Soerjomataram I, Jemal A, Bray F. Global patterns and trends in colorectal cancer incidence and mortality. Gut. 2017:66(4):683-91.

7. Hessami Arani S, Kerachian MA. Rising rates of colorectal cancer among younger Iranians: is diet to blame? Curr Oncol. 2017;24(2):e131-7.

8. Soltani M, Parivar K, Baharara J, Kerachian MA, Asili J. Putative mechanism for apoptosis-inducing properties of crude saponin isolated from sea cucumber (Holothuria leucospilota) as an antioxidant compound. Iran J Basic Med Sci. 2015;18(2):180-7.

9. Kune G, Watson L. Colorectal cancer protective effects and the dietary micronutrients folate, methionine, vitamins B6, B12, C, E, selenium, and lycopene. Nutr Cancer. 2006;56(1):11-21.

10. Ferrari A, Torrezan GT, Carraro DM, Aguiar Junior S. Association of folate and vitamins involved in the 1-carbon cycle with polymorphisms in the methylenetetrahydrofolate reductase gene (MTHFR) and global DNA methylation in patients with colorectal cancer. Nutrients. 2019;1 (6):1368

11. Lévesque N, Leclerc D, Rozen R. Folate and epigenetics: colorectal cancer risk and detection. Handb Nutr Diet Epigenet. 2017;66:1-19.

12. Cellarier E, Durando X, Vasson M, Farges M, Demiden A, Maurizis J, Madelmont J, Chollet P. Methionine dependency and cancer treatment. Cancer Treat Rev. 2003;29(6):489-99.

13. Frosst P, Blom H, Milos R, Goyette P, Sheppard CA, Matthews R, Boers G, Den Heijer M, Kluijtmans L, Van Den Heuve L. A candidate genetic risk factor for vascular disease: a common mutation in methylenetetrahydrofolate reductase. Nat Genet. 1995:10(1):111.

14. Esmaili MA, Kazemi A, Faranoush M, Mellstedt H, Zaker F, Safa M, Mehrvar $\mathrm{N}$, Rezvany MR. Polymorphisms within methotrexate pathway genes: relationship between plasma methotrexate levels, toxicity experienced and outcome in pediatric acute lymphoblastic leukemia. Iran J Basic Med Sci. 2020;23(6):800-9.

15. Sameer A. Colorectal cancer: molecular mutations and polymorphisms. Front Oncol. 2013:3(114):66.

16. Yin G, Kono S, Toyomura K, Hagiwara T, Nagano J, Mizoue T, Mibu R, Tanaka M, Kakeji Y, Maehara Y. Methylenetetrahydrofolate reductase C677T and A1298C polymorphisms and colorectal cancer: the Fukuoka Colorectal Cancer Study. Cancer Sci. 2004;95(11):908-13.

17. Shokrzadeh M, Mohammadpour A. Evaluation of a modified salt-out method for DNA extraction from whole blood lymphocytes: a simple and economical method for gene polymorphism; 2017.

18. González JR, Armengol L, Solé X, Guinó E, Mercader JM, Estivill X, Moreno V. SNPassoc: an R package to perform whole genome association studies. Bioinformatics. 2007;23(5):644-5.

19. Pieroth R, Paver S, Day S, Lammersfeld C. Folate and Its Impact on Cancer Risk. Curr Nutr Rep. 2018;7(3):70-84.

20. Chen J, Giovannucci E, Kelsey K, Rimm EB, Stampfer MJ, Colditz GA, Spiegelman D, Willett WC, Hunter DJ. A methylenetetrahydrofolate reductase polymorphism and the risk of colorectal cancer. Can Res. 1996;56(21):4862-4.

21. Slattery ML, Potter JD, Samowitz W, Schaffer D, Leppert M. Methylenetetrahydrofolate reductase, diet, and risk of colon cancer. Cancer Epidemiol Prev Biomark. 1999;8(6):513-8.

22. Ma J, Stampfer MJ, Giovannucci E, Artigas C, Hunter DJ, Fuchs C, Willett WC, Selhub J, Hennekens CH, Rozen R. Methylenetetrahydrofolate reductase polymorphism, dietary interactions, and risk of colorectal cancer. Can Res. 1997;57(6):1098-102.

23. Le Marchand L, Wilkens LR, Kolonel LN, Henderson BE. The MTHFR C677T polymorphism and colorectal cancer: the multiethnic cohort study. Cancer Epidemiol Prev Biomark. 2005;14(5):1198-203.

24. Chandy S, Sadananda Adiga M, Ramachandra N, Krishnamoorthy S, Ramaswamy G, Savithri H, Krishnamoorthy L. Association of methylenetetrahydrofolate reductase gene polymorphisms \& colorectal cancer in India. Indian J Med Res. 2010;131(5):659.

25. Otani T, Iwasaki M, Hanaoka T, Kobayashi M, Ishihara J, Natsukawa S, Shaura K, Koizumi Y, Kasuga Y, Yoshimura K. Folate, vitamin B6, vitamin B12, and vitamin B2 intake, genetic polymorphisms of related enzymes, and risk of colorectal cancer in a hospital-based case-control study in Japan. Nutr Cancer. 2005;53(1):42-50.

26. Matsuo K, Hamajima N, Hirai T, Kato T, Inoue M, Takezaki T, Tajima K. Methionine synthase reductase gene A66G polymorphism is associated with risk of colorectal cancer. Asian Pac J Cancer Prev. 2002;3(4):353-9.

27. Levine AJ, Figueiredo JC, Lee W, Poynter JN, Conti D, Duggan DJ, Campbell PT, Newcomb P, Martinez ME, Hopper JL. Genetic variability in the MTHFR gene and colorectal cancer risk using the colorectal cancer family registry. Cancer Epidemiol Prev Biomark. 2010;19(1):89-100.

28. Kennedy DA, Stern SJ, Matok I, Moretti ME, Sarkar M, Adams-Webber T, Koren G. Folate intake, MTHFR polymorphisms, and the risk of colorectal cancer: a systematic review and meta-analysis. J Cancer Epidemiol. 2012;66:2012.

29. Ting P-C, Lee W-R, Huo Y-N, Hsu S-P, Lee W-S. Folic acid inhibits colorectal cancer cell migration. J Nutr Biochem. 2019;63:157-64.

30. Pallem PVSP, Bodiga S, Bodiga VL. Dietary phytate lowers K-ras mutational frequency, decreases DNA-adduct and hydroxyl radical formation in azoxymethane-induced colon cancer. Iran J Basic Med Sci. 2020;23(1):20.

31. Nejad AL, Yaghoobi MM. Mutation analysis of TP53 tumor suppressor gene in colorectal cancer in patients from Iran (Kerman Province). Iran J Basic Med Sci. 2012;15(1):683.

32. Haghighi MM, Radpour R, Mahmoudi T, Mohebbi SR, Vahedi M, Zali MR. Association between MTHFR polymorphism (C677T) with nonfamilial colorectal cancer. Oncol Res. 2009;18(2-3):57-63.

33. Haerian MS, Haerian BS, Molanaei S, Kosari F, Sabeti S, Bidari-Zerehpoosh F, Abdolali E, Zali MR. MTHFR rs 1801133 polymorphism and susceptibility to colorectal cancer in Iranian population: evidence of a case-control study and meta-analysis. Pharmacogenomics. 2016;17(17):1957-65.

34. Jung AY, van Duijnhoven FJ, Nagengast FM, Botma A, Heine-Bröring RC, Kleibeuker JH, Vasen HF, Harryvan JL, Winkels RM, Kampman E. Dietary $B$ vitamin and methionine intake and MTHFR C677T genotype on risk of colorectal tumors in Lynch syndrome: the GEOLynch cohort study. Cancer Causes Control. 2014;25(9):1119-29.

35. Yin G, Ming H, Zheng X, Xuan Y, Liang J, Jin X. Methylenetetrahydrofolate reductase $\mathrm{C677T}$ gene polymorphism and colorectal cancer risk: a casecontrol study. Oncol Lett. 2012;4(2):365-9.

36. Zhao M, Li X, Xing C, Zhou B. Association of methylenetetrahydrofolate reductase $\mathrm{C} 677 \mathrm{~T}$ and $\mathrm{A} 1298 \mathrm{C}$ polymorphisms with colorectal cancer risk: a meta-analysis. Biomed Rep. 2013;1(5):781-91.

37. Le Marchand L, Donlon T, Hankin JH, Kolonel LN, Wilkens LR, Seifried A. B-vitamin intake, metabolic genes, and colorectal cancer risk (United States). Cancer Causes Control. 2002;13(3):239-48.

38. Friso S, Choi S-W, Girelli D, Mason JB, Dolnikowski GG, Bagley PJ, Olivieri $\mathrm{O}$, Jacques PF, Rosenberg $\mathrm{IH}$, Corrocher R. A common mutation in the 5, 10-methylenetetrahydrofolate reductase gene affects genomic DNA methylation through an interaction with folate status. Proc Natl Acad Sci. 2002;99(8):5606-11.

39. Keku T, Millikan R, Worley K, Winkel S, Eaton A, Biscocho L, Martin C, Sandler R. 5, 10-Methylenetetrahydrofolate reductase codon 677 and 1298 polymorphisms and colon cancer in African Americans and whites. Cancer Epidemiol Prev Biomark. 2002;11(12):1611-21.

40. Heijmans BT, Boer JM, Suchiman HED, Cornelisse CJ, Westendorp RG, Kromhout D, Feskens EJ, Slagboom PE. A common variant of the methylenetetrahydrofolate reductase gene (1p36) is associated with an increased risk of cancer. Can Res. 2003;63(6):1249-53.

41. Kim J, Cho YA, Kim D-H, Lee B-H, Hwang D-Y, Jeong J, Lee H-J, Matsuo K, Tajima K, Ahn Y-O. Dietary intake of folate and alcohol, MTHFR C677T polymorphism, and colorectal cancer risk in Korea. Am J Clin Nutr. 2012;95(2):405-12.

\section{Publisher's Note}

Springer Nature remains neutral with regard to jurisdictional claims in published maps and institutional affiliations. 